\title{
Os perfis femininos nas narrativas de Clodoaldo Freitas
}

\author{
The feminine profiles in narratives of Clodoaldo Freitas
}

\author{
Cleanne Nayara Galiza Colaço ${ }^{1}$ \\ Fabiana dos Santos Sousa ${ }^{2}$
}

\begin{abstract}
RESUMO
O artigo apresenta um estudo das obras Coisas da Vida ${ }^{3}$, Os Barretos ${ }^{4}, A$ besta humana 5 e Mãe dolorosa ${ }^{6}$, de Clodoaldo Freitas, com ênfase na análise das personagens femininas. Com isso, busca-se traçar os perfis femininos presentes em tais obras e notar a punição sofrida por aquelas que transgrediram os padrões da sociedade do século XIX.
\end{abstract}

PALAVRAS-CHAVE: Perfis femininos. Transgressão. Século XIX. Punição.

\section{ABSTRACT}

The article presents a study of the works Things in life, The Barretos, The human beast and The mother in pain, by Clodoaldo Freitas, with emphasis on the analysis of female characters. With this, it sought to trace the feminine profiles present in such works and to note the punishment suffered by those who have transgressed the standards of nineteenthcentury society.

KEYWORDS: Female profiles. Transgression. XIX century. Punishment.

\footnotetext{
1 Aprovada para o mestrado acadêmico em Literatura, Memória e Cultura pela Universidade Estadual do Piauí (início em março de 2019). Especialização em Docência do Ensino Superior e Supervisão Escolar pela Faculdade Evangélica do Meio Norte (FAEME). Graduada em Letras Português e Literatura pela Universidade Estadual do Maranhão (UEMA) e História pela Universidade Estadual do Piauí (UESPI).

2 Doutoranda em Materialidades da Literatura pela Universidade de Coimbra (UC) - Portugal. Mestre em Letras-Literatura pela Universidade Estadual do Piaú (UESPI). Especialização em Letras: Português e Literatura pelas Faculdades Integradas de Jacarepaguá (FIJ) - Rio de Janeiro. Especialização em Libras pela Universidade Federal do Piauí (UFPI). Graduada em Letras Português e Francês pela Universidade Federal do Piauí (UFPI).
}

1 FREITAS, Clodoaldo. Coisas da Vida. Imperatriz, MA: Ética, 2009.

${ }^{4}$ FREITAS, Clodoaldo. Um segredo de família e outros contos. Imperatriz, MA: Ética, 2009.

5 FREITAS, 2009.

${ }^{6}$ FREITAS, 2009. 
O final do século XIX para as primeiras décadas do século XX sofreu mudanças que perpassaram o social refletindo nos âmbitos das famílias, dos costumes, dos corpos, dos comportamentos de homens e mulheres, enfim, da sociedade em geral. Portanto, foi possível identificar diferentes perfis femininos evidenciados nas obras de Clodoaldo Freitas, a partir dos seguintes questionamentos: Quais perfis femininos foram encontrados em sua obra? Como o discurso do literato Clodoaldo Freitas corrobora com a visão depreciativa da mulher veiculada naquele contexto? De que modo são impressas as normas em relação ao corpo feminino na escrita do autor?

Clodoaldo Freitas está inserido em uma configuração característica da época, centrada por homens letrados, advindos de universidades tradicionais, especialmente da academia de Direito. Nessa perspectiva, ser um intelectual deste período não só significava ter uma formação acadêmica, mas procurar engajar a escrita de forma combatente, além de representar as subjetividades do autor, mostrando as impressões do mundo ao seu redor. ${ }^{7}$ Formou-se em Direito na Faculdade de Recife, nascido em Oeiras, interior da província do Piauí, no ano de 1855, Clodoaldo Severo Conrado de Freitas $^{8}$, possui uma trajetória intensa e engajada como um intelectual da época.

No Brasil, o período que se localiza na transição do século XIX para o século XX foi permeado por mudanças, pois podemos observar gradual transformação através do contexto social advindo dos primeiros anos da República. Nesse período, podemos identificar uma transição, pois a partir de ideais de modernidade que emergiram a partir do regime republicano, a sociedade brasileira atravessou mudanças sociais e culturais. ${ }^{9}$

Segundo José Murilo de Carvalho, "os propagandistas e os principais participantes do movimento republicano rapidamente perceberam que não

\footnotetext{
7 SEVCENKO, Nicolau. Literatura como missão: tensões sociais e criação cultural na Primeira República. São Paulo: Brasiliense, 1999.

8 GONÇALVES, Wilson Carvalho. Antologia da Academia Piauiense de Letras. Teresina: Halley, 2007. p. 140.

9 CARVALHO, José Murilo de. Os bestializados: o Rio de Janeiro e a República que não foi. São Paulo: Companhia das letras, 1987.
} 
se tratava da república de seus sonhos" 10 Isso provavelmente pelo fato de as mudanças de um regime político para outro, no caso da Monarquia para a República, não atender a todas as expectativas propostas por seus idealizadores e em meio às contradições do regime vigente, podemos identificar desde as tentativas de sua implementação, tensões políticas nessa transição desse sistema político.

No que se refere à circulação de suas obras, neste período, as produções escritas eram publicadas nos jornais vigentes da época e quando nos reportamos à escrita de Clodoaldo Freitas, seus contos foram também publicados em jornais de época ${ }^{11}$, a exemplo, Os Barretos $^{12}$, $A$ besta humana $^{13}$ e Mãe dolorosa ${ }^{14}$ e o romance Coisas da Vida ${ }^{15}$ publicado originalmente entre os anos de 1908 e 1909, igualmente no Diário do Maranhão. Através da literatura articulada com o discurso social e historiográfico, podemos percorrer os diversos caminhos traçados e refletirmos sobre o tratamento dado à mulher por meio de seu corpo. Nesse sentido, objetivamos traçar os perfis femininos presentes nas referidas obras de Clodoaldo Freitas.

Nas perspectivas dos estudos relacionados à mulher está implícito um estudo concernente ao seu corpo. Este que antes tinha um caráter naturalizado deve ser pensado como algo socioculturamente construído e moldado por padrões que alicerçam a sociedade. E deixando claro que aqueles que infringem tais padrões são criticados, subjulgados e, também, silenciados, ou seja, aqueles que saem da condição de "corpos dóceis" - "é

${ }^{10}$ CARVAlHO, José Murilo de. Entre a liberdade dos antigos e a dos modernos: A República no Brasil. In: CARVALHO, José Murilo de. Pontos e Bordados. Belo Horizonte: UFMG, 1998. p. 102.

${ }^{11}$ COSTA, Mara Lígia Fernandes. A escrita e o desejo: as relações de gênero na produção literária de Clodoaldo Freitas. (Dissertação) Programa de Pós-graduação em História do Brasil, Universidade Federal do Piauí. Teresina, 2010.

${ }^{12}$ FREITAS, Clodoaldo Freitas. Um segredo de família e outros contos. Imperatriz, MA: Ética, 2009. (Conto publicado originalmente no Diário do Maranhão, São Luis, nos dias 7 à 14 de outubro de 1907).

${ }^{13}$ FREITAS, Clodoaldo Freitas. Um segredo de família e outros contos. Imperatriz, MA: Ética, 2009. (Conto publicado originalmente no Diário do Maranhão, São Luis, nos dias 7 à 14 de outubro de 1907).

${ }^{14}$ FREITAS, Clodoaldo Freitas. Um segredo de família e outros contos. Imperatriz, MA: Ética, 2009. (Conto publicado originalmente no Diário do Maranhão, São Luis, nos dias 7 à 14 de outubro de 1907).

${ }^{15}$ FREITAS, Clodoaldo. Coisas da Vida. Imperatriz, MA: Ética, 2009. ( Publicação original no Diário do Maranhão entre os meses de dezembro à janeiro de 1908 a 1909). 
dócil um corpo que pode ser submetido, que pode ser utilizado, que pode ser transformado e aperfeiçoado”. (FOUCAULT, 1987, p.118) - sofrem punições pela desobediência às normas impostas. Assim sendo, é possível pensar que papeis e rótulos foram criados e agregados ao corpo para que ele tome a forma desejada pelo poder social, principalmente no que diz respeito ao corpo feminino. Isso porque

o corpo também está diretamente mergulhado num campo político; as relações de poder têm alcance imediato sobre ele; elas o investem, o marcam, o dirigem, o supliciam, sujeitam-no a trabalhos, obrigam־no a cerimônias, exigem-lhe sinais. Este investimento político do corpo está ligado, segundo relações complexas e recíprocas, à sua utilização econômica; é uma boa proporção, como força de produção que o corpo é investido por relações de poder e de dominação; [...] o corpo só se torna força útil se é ao mesmo tempo corpo produtivo e corpo submisso. ${ }^{16}$

Esta submissão provocada pelas relações de poder de que Foucault fala é facilmente observada em nossa sociedade, principalmente no que se refere à desigualdade social dos gêneros. $\mathrm{O}$ corpo feminino vem sendo, ao longo dos tempos, subordinado ao masculino, visto que este é munido do poder social sobre aquele.

As concepções reveladas até aqui em relação ao corpo remetem a um conceito de que ele é socialmente construído. Tais concepções dependem de um conjunto de situações, vivências, comportamentos diante da família, do Estado e da sociedade como um todo. Esse discurso emerge na sociedade estabelecendo novos comportamentos e ideais que passaram a ser normatizados.

Em vista disso, os estudos relacionados ao corpo vêm crescendo cada vez mais e, de acordo com pesquisas recentes, destacamos que ele vai além do biológico, como já afirmamos. Para Joana de Vilhena Novaes "Da moda do corpo ao corpo da moda, corpo natural se desnaturaliza ao entrar em cena, conforme as exigências impostas pelos modelos vigentes ou pelo poder

16 FOUCAULT, Michel. Vigiar e punir. Petrópolis: Vozes, 1987, p.25-26. 
das normas organizadoras do ethossócio-cultural. Mas esse corpo não é apenas passivo: ele transgride, cria, rebela-se - por que fala."17

Esse corpo transgressor é colocado em cena nas obras de Clodoaldo Freitas, uma vez que o autor apresenta mulheres que buscam atender aos seus anseios corporais, evadindo-se da condição de "corpo dócil" ao transgredir os comportamentos ideais padronizados pela sociedade.

No discurso literário, os homens de escrita engajada receberam influência desse contexto que estava ao seu redor. Nesse sentido, a escrita de Clodoaldo Freitas nos revela através de um conjunto ficcional algumas características no que consiste à desigualdade referente às relações de gênero, os comportamentos normatizados da sociedade naquele contexto e a representação do corpo feminino.

$\mathrm{Na}$ análise de alguns contos do literato Clodoaldo Freitas, encontramos em $A$ besta humana e Os Barretos a presença da violência contra mulher e as punições recorrentes a esta que ultrapassam as leis e a moral da sociedade. Punições essas atribuídas e realizadas pelas mãos de qualquer homem que sinta sua superioridade e sua honra ferida pela atitude "desrespeitosa" de alguma mulher, dentre elas, a escolha de um companheiro a quem seu coração/corpo aspira.

No conto OS Barretos, destaca-se na obra a "traição" de Inácia, a mulher de Pedro Barreto, com o personagem Manezinho. Pedro Barreto sentia muito ciúme de Inácia, devido a sua beleza e seus encantos, o que, na visão dele, eram exclusivamente seus. Dessa forma, ele acabou por transformar o que sentia por ela em um sentimento de posse, conferindo à Inácia a condição de objeto possuído por um dono. Barreto com o passar do tempo, embebido por seus ciúmes, acreditava cada vez mais na traição de Inácia:

Daí em diante o Barreto começou aparecer em casa inesperadamente, sem notar modificação alguma nos hábitos da mulher. Deixou de aparecer de surpresa. No primeiro domingo, vestindo o filhinho mais velho, saiu com

\footnotetext{
17 NOVAES, Joana de Vilhena. Beleza e feiura: corpo feminino e regulação social. In: DEL PRIORE, Mary; AMARANTINO, Márcia. (orgs) História do corpo no Brasil. São Paulo: Unesp, 2011. p. 478. 
ele a passeio para os lados do açude. Dominava-o uma ideia monstruosa: interrogar o menino, saber dele a vida da Inácia. Andaram muito tempo. O Barreto não tinha coragem de fazer do menino delator. Achava uma infâmia isto. Mas o ciúme o enlouquecia. ${ }^{18}$

No desenvolvimento do conto, de tanto desconfiar, Barreto acaba encontrando evidências sobre o adultério e, ao acordar numa manhã, observa que Inácia tinha ido embora de casa.

Não podia acreditar na infâmia da mulher. De mistura com o seu ódio, sentia uma piedade infinita pela desventura dela. Sentia, juntamente com o seu ciúme, a mágoa de vê-la infamada, perdida, trilhando essa escura vereda lamacenta e coberta de urzes. Pensava em mim coisas desconexas e sinistras. Tinha vontade de matá-la. ${ }^{19}$

$\mathrm{O}$ que se nota pelas duas citações anteriores, referentes ao conto $O_{S}$ Barretos é que Pedro Barreto, tomado pelos sentimentos de posse e ciúme e, ainda, por saber que a beleza de Inácia poderia despertar desejos em muitos outros, concebeu em sua mente que a esposa o traia e, por isso, passou a perseguir Inácia que, de tanto sofrimentos, acaba por fugir de casa.

O marido de Inácia, após colher informações, descobriu que ela estava morando com Manezinho. "Inácia estava de casa posta, morando com Manezinho para os lados da rua do Sol. O Barreto sofreu um choque violento." 20 E ele acabou indo ao seu encontro e com toda a fúria e violência, matou-a: "O Barreto desceu o braço rígido e um jato de sangue bateu-lhe no rosto cadavérico [...] era tarde. A facada atingira o coração." ${ }^{21} \mathrm{~A}$ atitude de Barreto, retrata o domínio patriarcal sobre as mulheres que as impedem até mesmo de pensar uma vida que não esteja sob os padrões sociais.

A dominação masculina foi, e, mesmo que de forma menos intensa, continua sendo determinante sobre a vida das mulheres. A mulher tem sido

\footnotetext{
18 FREITAS, 2009. p. 91.

19 FREITAS, 2009. p. 94.

20 FREITAS, 2009. p. 95.

${ }^{21}$ FREITAS, 2009. p. 99.
} 
ocultada pelo homem, restando lhe apenas a posição de outro, e ele sempre dono do poder. É o que declara Bourdieu:

A posição de um determinado agente no espaço social pode assim ser definida pela posição que ele ocupa nos diferentes campos, quer dizer, na distribuição dos poderes que actuam em cada um deles seja, sobretudo, o capital económico, o capital cultural e o capital social e também capital simbólico. ${ }^{22}$

Considerando o que diz Bourdieu na citação anterior sobre a posição de uma pessoa depender dos diferentes capitais de que ela dispõe, a mulher está em desvantagem em relação ao homem, pois ela não dispõe de todos desses capitais, assim sendo, não tem o poder de decidir, por exemplo, findar ou não um casamento como tentou Inácia depois das pressões do marido. Desprovida de tais poderes, ela não é digna de respeito e reconhecimento perante a sociedade.

Ainda segundo Bourdieu (idem), "O mundo social pode ser dito e construído de diferentes modos: ele pode ser praticamente percebido, dito, construído, segundo diferentes princípios de visão", e é de interesse do homem fazer prevalecer seu ponto de vista, dizer e construir o mundo à sua maneira para assim dominá-lo sem a interferência das mulheres.

Considerando que os indivíduos que fazem a sociedade são divididos em sexos, a estes são atribuídos papéis sociais diferentes. Isso com base:

única justificativa: argumentar sobre a diferença dos sexos. É por isso que esse velho discurso retoma no século XIX um novo rigor, apoiando-se nas descobertas da medicina e da biologia. É um discurso naturalista, que insiste na existência de duas "espécies" com qualidades e aptidões particulares. Aos homens, o cérebro, a inteligência, a razão lúcida, a capacidade de decisão. Às mulheres, o coração, a sensibilidade, os sentimentos. (PERROT, 1988, p.177).

${ }^{22}$ BOURDIEU, Pierre. O Poder Simbólico. 12ª ed. Rio de Janeiro: Bertrand Brasil, 2009. p. 134. 
Nesta perspectiva, o patriarcalismo criou a ideia de que o homem deve ter o controle de tudo, inclusive da família, o que inclui a mulher, isso porque se defende o pensamento da "inaptidão radical do sexo feminino para o governo, mesmo da simples família", em virtude da "espécie de estado infantil contínuo" que caracteriza o sexo feminino". (COMTE apud PERROT, 1988, p.178). Nesse sentido, observa-se o quão munido desse pensamento patriarcal estava Barreto ao se achar no direito de tirar friamente a vida de Inácia por ela se sentir no direito de não mais querer viver com ele e ser feliz em outro relacionamento.

No conto $A$ besta humana, encontramos semelhante presença da violência contra a mulher. Bernadinho é casado com D. Virgolina, com quem tem dois filhos, mas é obcecado por Etelvina. Com o objetivo de dar maior educação aos filhos contrata Etelvina, "uma moça diplomada pela Escola Normal de Fortaleza, viesse encarregar-se da educação dos filhos." 23 Ao conhecer a professora, sente um enorme desejo por ela, o que, com o tempo, cresce cada vez mais até se transformar em obsessão. Ele queria possuí-la, mas ela não o aceitava, pois além de ser prometida a um rapaz de sua terra natal, Bernadinho era um homem casado.

No transcorrer do conto tal obsessão torna-se mais evidente, ele começa a ameaçá-la de morte, queria tê-la sexualmente viva ou morta. Assassinou Etelvina com três tiros e ainda manteve contato sexual com seu cadáver.

Bernadinho apagou a lâmpada que iluminava o quarto fúnebre e abraçouse com o cadáver. Ouviam-se perfeitamente os seus beijos e as palavras ternas murmuradas nos seus loucos afagos. Aquela paixão imensa e desordenada, que fora até o homicídio, se saciava estupidamente num cadáver ainda quente. ${ }^{24}$

Diante dos relatos expostos, sobre personagens Etelvina e Inácia, encontramos dois diferentes perfis femininos. A primeira enquadra-se na mulher de caráter virginal, que está preparada para o casamento, aquela

\footnotetext{
${ }^{23}$ FREITAS, 2009. p. 45.
}

${ }^{24}$ FREITAS, 2009. p. 55. 
que aceita o destino que lhe foi traçado por aquele que tem o poder de decidir sobre sua vida amorosa ou não, o homem. Mas por ter resistido a atender os anseios sexuais daquele que é seu patrão, é assassinada. Inácia, por tomar a decisão de findar o casamento, foi severamente assassinada pelo marido.

Em A Dominação Masculina (2007), Bourdieu diz que a força da ordem se evidencia no fato de que ela dispensa justificação. A visão androcêntrica impõe-se como neutra e não tem necessidade de se enunciar em discursos que visem legitimá-la.

A ordem social funciona como uma imensa máquina simbólica que tende a ratificar a dominação masculina sobre a qual se alicerça: é a divisão social do trabalho, distribuição bastante estrita das atividades atribuídas a cada um dos dois sexos, de seu local, seu momento, seus instrumentos; é a estrutura do espaço, opondo o lugar de assembleia ou de mercado, reservados aos homens, e a casa reservada às mulheres; ou, no interior desta, entre a parte masculina, com o salão, e a parte feminina, com o estábulo, a água e os vegetais; é a estrutura do tempo, a jornada, o ano agrário, ou o ciclo da vida, com momentos de ruptura, masculinos, e longos períodos de gestação, femininos. ${ }^{25}$

Ou seja, a própria organização social foi criada de forma a reafirmar a autoridade de um sexo sobre o outro - homem sobre a mulher - sem que esta possa se quer questionar o porquê da sua marginalização frente à sociedade, uma vez que em todos os setores de atividades trabalhistas ou não, ela se encontra em desvantagens. A afirmação de Bourdieu evidencia-se no conto $A$ besta humana, pois Etelvina foi assediada no setor de trabalho pelo então patrão, Bernardinho, o que nos permite observar que mesmo a mulher tida como "independente" financeiramente não está livre do machismo que permeia nossa sociedade, uma vez que nota-se que o patrão não aceita a "rebeldia" da moça e pune-a cruelmente por isso.

\footnotetext{
${ }^{25}$ BOURDIEU, Pierre. A dominação masculina. $5^{\mathrm{a}}$ ed. Rio de Janeiro: Bertrand Brasil, 2007. p. 18.
} 
Embora os contos tenham sido escritos no final do século XIX para início do XX, período em que a mulher era, pode-se dizer, totalmente desprovida de direitos sociais, eles se mostram muito atuais. Inácia e Etelvina representam as muitas mulheres assassinadas diariamente simplesmente pelo ciúme doentio do marido ou namorado ou por resistirem ao assédio masculino (seja no local de trabalho ou fora dele): basta ligarmos a TV para vermos os inúmeros noticiários mostrarem fatos que retratam o feminicídio que ocorre no Brasil e no mundo. Tal realidade nos permite constatar que o patriarcalismo e o machismo continuam presentes e, em nome deles, inúmeras mulheres são mortas todos os dias. Isso pode ser explicado pelo fato de que, como Etelvina e Inácia, as mulheres vêm, gradativamente, tomando consciência da condição subalterna em que vivem na sociedade e lutam pela isonomia social. As relações de poder destacadas por Bourdieu anteriormente nesta pesquisa seguem existindo e beneficiando o homem que, dele munido, usa`o para silenciar, seja de que forma for, a mulher.

Outra obra em que Clodoaldo Freitas traz à tona questões relacionadas às mulheres é o conto Mãe dolorosa ${ }^{26}$. Neste, a narrativa inicia-se com a memória do narrador lembrando de Maria, uma mulher de grande beleza e mocidade pela qual ele tinha se apaixonado. Mas logo é revelado no conto que ela tinha morrido de parto. "Quando me vieram dizer que Maria acabava de morrer de parto, senti um choque violentíssimo." 27 Revelando o caráter de punição dos perfis que subvertiam a conduta que lhes era prescrita socialmente, uma vez que Maria não exercia um trabalho honesto, conforme os padrões sociais, já que vivia da venda de seu corpo. Porém, a gravidez significava a remissão dos seus atos miseráveis, pois ela iria exercer um papel fundamental para a figura feminina, o de ser mãe.

- Um filho seria a minha remissão e me daria coragem para o trabalho honesto. - E não vives do trabalho honesto? - Trabalho, mas não vivo só do meu trabalho honesto. Entendia e calei. - E assim mesmo, vou ser mãe! - mussitou ela, tragando um soluço. - Se meu filho, depois de

\footnotetext{
${ }^{26}$ FREITAS, Clodoaldo. Mãe dolorosa. In: FREITAS, Clodoaldo. Um segredo de família e outros contos. Imperatriz, MA: Ética, 2009. p. 203 - 211.

27 FREITAS, 2009, p. 203. 
homem, tendo conhecido da minha miséria, tiver vergonha de mim e desprezar-me? Quantas vezes penso nisto! 28

Mostrando que Maria foi enganada em sua vida, ficou grávida, sozinha, sem um marido para apoiá-la e ainda trabalhava vendendo seu corpo. "Por que eu sou uma miserável criatura que desceu ao mais baixo degrau da vida e vive à mercê das suas vergonhas e misérias." ${ }^{29}$ E como correção de sua vida desregrada e fora dos padrões morais e religiosos, a morte foi a sua redenção.

Até aqui, é possível entender que as personagens femininas de Clodoaldo Freitas representam as características que emergiram na sua época, os valores conservadores continuavam em torno das mulheres. Estas têm seu papel social delimitado, a saber, o de ser esposa, mãe, mantenedora do lar, e aquelas que se recusavam a exercer tal função teriam sua imagem relacionada à decadência social. O único meio de que dispunham para ascender socialmente era o casamento, a remissão dos seus maus atos seria pela maternidade, e a punição, a morte.

Portanto, podemos compreender pela escrita de Clodoaldo Freitas que o corpo feminino está sujeito a penalidades caso contrarie às ordens impostas pelo sistema social patriarcal vigente, o que corrobora com o pensamento da sociedade do século XIX e, como vimos, da atual também, na qual o corpo feminino, socialmente construído, está submetido aos mandos e desmandos do sujeito masculino.

No que se refere ao romance Coisas da vida, do mesmo autor, verificase que ele está inserido num contexto referente à época dos engenhos, na qual as famílias apresentadas na obra são aquelas que representam a nobreza daquele período, em que reinam o patriarcalismo e a predominância dos dogmas religiosos que permeavam as famílias, pregando a moral, a castidade, as relações direcionadas ao casamento.

As publicações desse romance ocorreram entre os anos de 1908 e 1909 no jornal Diário do Maranhão, na capital São Luis, através dos folhetins

\footnotetext{
28 FREITAS, 2009, p.207.

29 FREITAS, 2009, p.205. 
semanais que percorreram nos meses de dezembro a janeiro. ${ }^{30}$ Mas o contexto geral da escrita de Clodoaldo Freitas é ambientado nos anos anteriores, o que nos reporta tanto para o recorte temporal e social do ano das publicações como para o contexto temporal e social das obras. Podemos perceber como uma das características do autor esta prática de suas obras serem evidenciadas aos períodos anteriores, então podemos identificar a presença de suas memórias, concepções e aproximação para o seu passado, dando ao autor, também, características de historiador.

A obra Coisas da Vida apresenta-se inovadora, pois ela é despida da exaltação feminina, idealização e da castidade tão típicas dos aspectos literários do contexto. Embora as mulheres apresentadas pertençam à classe nobre conservadora, elas buscam satisfazer os desejos sexuais sentidos por seus corpos independentes de estarem casadas ou não.

Coisas da vida narra a história de Plínio, um estudante de direito (típico desse contexto) que vai passar alguns dias com a família de seu melhor amigo, Netário. O pai de Netário é o comendador Herculano Cavalcante, dono de uma fazenda no interior de Pernambuco e casado com a senhora Camila, sua segunda esposa, de apenas vinte anos. O comendador é ainda pai de mais duas moças, Anica e Carlota, também frutos do seu primeiro casamento, assim como Netário. Há ainda Crescêncio, um parente distante que mora com eles na fazenda.

No decorrer da obra, as personagens femininas vão aparecendo, revelando suas sexualidades, nos levando à aproximação das concepções do corpo feminino e nos fazendo compreender uma nova alternativa para o modo de vida das mulheres da elite da época, não mais restrita à ideia da frigidez feminina. ${ }^{31}$ Uma elite patriarcal, na qual o homem era o detentor do poder e do espaço público, enquanto às mulheres era destinado o ambiente privado, a exemplo, o lar, visto que não possuíam muitas ocupações. Essa

\footnotetext{
${ }^{30}$ QUEIROZ, Teresinha. Os literatos e a República: Clodoaldo Freitas, Higino Cunha e as tiranias do tempo. Teresina: Fundação Cultural Monsenhor Chaves, 1994. 305 p.

${ }^{31}$ MATOS, Maria Izilda de. SOIHET, Raquel. O corpo feminino em debate. São Paulo. UNESP, 2003.
} 
falta de ocupação levava as mulheres ao imaginário do amor romântico, da idealização dos romances, bem como do amor carnal.

As senhoras divertiam-se durante o dia, no trabalho ou lendo algum romance dos mais sentimentais e devotos que o comendador escolhia, entre outros, Graziela, Regina, Rafael, Paulo e Virgina, Atala. Nessas leituras prejudiciais, funestas aos espíritos juvenis, sem o contrapeso de uma educação séria, as três moças saturavam-se de impressões violentas e carnais. ${ }^{32}$

As personagens femininas estão distantes da idealização, mas estão próximas dos desejos da juventude permeados de sensações. Mulheres nobres que sentem desejos tão intensos que as levam a cometer adultério em nome de um querer, de um prazer, deixando de lado o caráter de mulheres virginais. Nesse sentido, Plínio, diante de jovens tão belas e formosas, envolve-se com D. Camila (casada) e Carlota (enteada), além de outras jovens que aparecem na trama, como Hermínia, Rosina e Hortência.

Todas essas personagens representam as mulheres do contexto daquela época: jovens, belas e formosas, características ideais de um corpo desejado. Clodoaldo Freitas, em sua vivência no mundo das letras, deixou claro o quanto apreciava a beleza feminina e imprimiu seu gosto em seus versos e romances, além das preocupações com os aspectos políticos e religiosos anticlericais.

Plínio, como era um homem letrado e leitor de romances, levava consigo as concepções do amor e interessava-se por vivê-lo, se possível, romântico, sentimento que podia ser observado nos livros e que se fazia presente na vida dos jovens daquele contexto:

Digo que na minha idade, não é um delito amar. Mas acrescento que, sem amar, um rapaz nas minhas condições pode procurar, no silencio, o oxigênio que o salão não lhe fornece à alma. Não sei se amo, porque desconheço completamente a influência do amor. Não me preocupo com

\footnotetext{
32 FREITAS, 2009. p. 8.
} 
isto agora, pela razão simplíssima de ainda não ter sido atingido pelas

flechas do cupido. ${ }^{33}$

Diante de tantas mulheres que lhe despertaram interesses que vão além da razão, Plínio acaba por envolver-se com praticamente todas elas, uma vez que é assediado por cada uma delas. Ainda assim persistia a presença da noção de família em Clodoaldo Freitas, bem como em outros literatos do século XIX. ${ }^{34}$

Um ponto de destaque no romance são as iniciativas que não somente partem do homem, o que é tradicional nas relações amorosas, mas, principalmente, partem também das mulheres que sentem o desejo pelo ser amado. Como aconteceu com D. Camila que, embora casada com o comendador Cavalcante, não hesitou em expressar seu desejo por Plínio, o que é notado desde o início da narrativa quando ela deixa claro que almeja o mesmo tratamento pessoal dado por ele em relação as suas enteadas Carlota e Anica. ${ }^{35}$ E no desenrolar do enredo, os dois desenlaçam um caso amoroso. "Camila enlaçou-me pelo pescoço e nossos lábios se colaram num beijo prolongado e ardente." 36

A ousadia de D. Camila permite observar seu caráter transgressor, uma vez que ela descumpriu o comportamento padrão de uma senhora casada. Ela jamais seria "perdoada" pela sociedade por cometer tal ato desrespeitoso contra a honra do marido caso fosse descoberta, pois na sociedade do século XIX, e por que não dizer na de hoje, a mulher deve se relacionar e se manter fiel a apenas um homem, caso contrário terá que conviver com o mal julgamento da sociedade por ter infringido as normas de comportamento da mulher.

A narrativa continua e os arranjos amorosos se revelam. Plínio pede Carlota em casamento ao mesmo tempo em que se envolve com Rosina, Hortência e, claro, com D. Camila. No diálogo entre Plínio e D. Camila é possível perceber a delicada situação:

\footnotetext{
33 FREITAS, 2009, p. 25.

${ }^{34}$ CASTELO BRANCO, Pedro Vilarinho. História e Masculinidades: a prática escriturísticas dos literatos e as vivências masculinas no início do século XX. Teresina: EDUFPI, 2008.

35 FREITAS, 2009, p. 10.

36 FREITAS, 2009, p. 25. 
- Não te cases com Carlota - disse ela, beijando-me. É uma mulher de gênio infernal, ciumenta e odienta. - Vou casar-me com Rosina. - Não devias casar-te. Destas moças, a única meiga e boa é a Hortência. - É uma tola. - Em regra as pessoas tolas têm um bom coração. Desprendeu-se dos meus braços e saiu resvalando pela sombra misteriosa. Corri atrás dela e tornei a estreitá-la loucamente nos braços e emudecemos de novo na ânsia do gozo infinito. - Amanhã te espero no meu quarto - disse-lhe. ${ }^{37}$

O que é impressionante é que D. Camila não parece preocupada ou com ciúmes com o fato de Plínio casar com outra, e também o fato de ela não pedir a ele para ficar com ela somente. Percebe-se apenas que ela o aconselha a casar com a mais "tola", o que nos leva a perceber que ela não pretende manter uma relação estável com Plínio, em consolidar o amor dos dois através do casamento, mas somente continuar atendendo aos desejos sexuais do seu corpo, em saborear sempre o gozo do amor que os dois fazem, mesmo depois que ele casar.

Em outro momento, Hortência declara-se a Plínio: "Se não tem compromissos com as filhas do comendador, tem repugnância de os tomar comigo? Eu o amo tanto." 38 O autor evidencia os desejos que tais mulheres despertavam em Plínio por serem jovens e muito belas. O protagonista teve seus encontros com D. Camila, Hortência, Carlota e Rosina. Depois de vários arranjos e rompimentos de promessas de casamento - à Rosina e à Carlota Plínio acaba fixando noivado com Hortência, mas sem se desprender de seus outros amores:

Na hora aprazada, debaixo dos jambeiros, encontrei Rosina e a mesma cena divinal fez nossos corpos se saturarem de um gozo, que nem os bemaventurados experimentam no céu. Esses encontros se reproduziam frequentemente aí. Ao meu quarto, que tinha entrada reservada pela horta, de vez em quando ia Camila ou Carlota. ${ }^{39}$

E os encontros continuavam ora com D. Camila, ora com Carlota, ora com Hortência, que ficara designada como sua noiva, ora com Rosina, que para Plínio

\footnotetext{
37 FREITAS, 2009, p. 45.

38 FREITAS, 2009, p. 21.

39 FREITAS, 2009, p. 74. 
era a mais sensual: "Mulheres! Mulheres! E há ainda quem se iluda com os risos de inocência, com esses gestos de pudor! De todas elas a mais bela e voluptuosa era Rosina. Que criatura soberba de carnação e volúpia." ${ }^{40}$

E novamente nos enlaçamos como duas jiboias no cio. Os galos cantavam. Era da visita de Camila. Separamo-nos. - Até amanhã! Beijei-a sofregamente e parti saturado de gozo, tonto de delícias. Meia hora depois estava nos braços de Camila. Meu Deus, porque essa vida não durou uma eternidade! O céu será diferente e melhor? ${ }^{41}$

E assim, elas e ele gozavam dos prazeres oferecidos no ato do saciamento dos desejos corporais. Porém, as escolhas dessas mulheres de vivenciarem seu amor, de revelarem seus desejos carnais ao ser amado, utilizando das armas da sedução de que dispunham, tiveram suas consequências.

Plínio casou-se com Rosina, mas gozaram de um curto tempo da vida de casados, visto que Antonio Cândido, que era apaixonado por Rosina e para quem esta era prometida desde criança - mas o recusara -, inconformado com a recusa de Rosina, assassinou-a e em seguida suicidouse.

Entrei e dei um grito de horror: Rosina era cadáver. - Que foi isto? perguntei soluçando freneticamente. D. Adelaide caiu gritando alucinadamente em meus braços. - Meu filho, mataram a nossa Rosina. Ah! Malvados! - Ignoro o que se passou, D. Adelaide. Ela, então, entre soluços, contou-me, que indo pela rua Brigadeiro Tobias, saiu-lhes ao encontro o Antônio Cândido e desfechara dois tiros de revólver em Rosina e, em seguida, suicidara-se. ${ }^{42}$

Meses depois, Plínio casa-se com Carlota, que também seria vítima fatal de um trágico incidente:

Como sua saúde reclamasse maiores cuidados, combinamos que iriam para os Poços de Caldas passar o mês de setembro. Carlota a

\footnotetext{
40 FREITAS, 2009, p. 78.

41 FREITAS, 2009, p. 79.

${ }^{42}$ FREITAS, 2009, p. 93.
} 
acompanharia. Partiram. No dia seguinte recebi um telegrama dando-me uma terrível notícia: ao desembarcarem na estação, Carlota foi desastradamente apanhada por um carro e morreu esmagada! ${ }^{43}$

Depois da morte da segunda esposa, Plínio volta para o engenho em Pernambuco e casa-se com Hortência e ela logo engravida. Contudo, os dias felizes foram interrompidos por um novo infortúnio:

Em um desses passeios, já de volta, no pátio da casa, vinham os vaqueiros com um boi arremetendo, tivemos de correr um grande espaço para nos abrigarmos no engenho. Hortência tomou um grande susto e daí foi conduzida para casa em braços. Manifestaramse os sintomas do aborto, que se realizou nessa mesma noite. E em seguida, terrível hemorragia, que a fulminou pela madrugada. Era uma fatalidade medonha, essa que me perseguia assim. ${ }^{44}$

Logo, Plínio estava nos braços de D. Camila novamente. Porém, esta acaba por aceitar sua condição de mulher casada. Ela vivencia os encontros amorosos com Plínio, mas não deixa sua função social, a de esposa e dona do lar, à qual a mulher é destinada. Assim sendo, seu desfecho foi continuar com seu marido Herculano.

- Agora eu posso morrer - dizia-me entre beijos, Camila. Gozei o teu amor como pedia a Deus que me concedesse gozá-lo. - Estás saciada? O comendador encontrou Camila melhor, com as cores naturais e com o espírito desanuviado. Vinha buscá-la, pois tinha urgência de voltar a Pernambuco, onde seus negócios o chamavam, Partiram. Na última noite que passamos juntos, o comendador dormiu narcotizado. Nosso amor ia em caminho do crime. Felizmente eles partiram e não os acompanhei até o Rio. ${ }^{45}$

Com a partida de Camila, Plínio poderia seguir sua vida livremente, pois todos os seus caminhos tortuosos foram silenciados, como se tivessem punidas pelo comportamento transgressivo. Ele logo casou com Adélia, que era sua prometida

\footnotetext{
43 FREITAS, 2009, p. 96.

${ }^{44}$ FREITAS, 2009, p. 100.

45 FREITAS, 2009, p. 97 - 98. 
desde a infância e seguiu sua vida. "Casei-me com Adélia e hoje sou fazendeiro e pai de numerosa prole. Deus abençoou o meu trabalho. Vivo feliz e em abastança, tendo encontrado em Adélia a esposa que pedia a Deus me desse." ${ }^{46}$

Pelo desfecho dado às personagens femininas subversivas de Coisas da vida, é possível perceber o caráter conservador da escrita de Clodoaldo Freitas, o que confere um caráter punitivo em torno daquelas que transgridem, que vivenciam sua sexualidade, ultrapassando os limites morais sociais, os quais delegavam à mulher o papel de esposa, mulher fiel ao marido e à família, cuja função essencial é a de ser mãe.

\section{Considerações finais}

Pelas análises aqui realizadas, foi possível constatar que a obra de Clodoaldo Freitas denota uma diversidade de perfis em torno da mulher: Inácia representa aquelas mulheres que sofreram e ainda sofrem (atualmente) devido o ciúme doentio de seus companheiros. Etelvina simboliza aquelas que viveram e ainda vivem sob o assédio sexual no ambiente de trabalho ou fora dele. As duas, por tomarem decisões que contrariavam as vontades dos sujeitos homens, foram friamente assassinadas por eles.

Em Coisas da vida, embora o autor tenha dado liberdade às personagens femininas (D. Camila, Rosina, Carlota e Hortência) para vivenciar experiências sexuais as quais desejavam, não puderam viver felizes após tais experiências e, por isso mesmo, foram severamente punidas com finais trágicos: D. Camila teve que se conformar, aceitar e submeter-se à condição de senhora casada, representando, dessa forma, as inúmeras mulheres que, em nome da honra e da moral, sujeitam-se a viverem em casamentos infelizes por toda a vida; Rosina foi assassinada por rejeitar aquele a quem sempre foi prometida (Antônio Cândido) em nome do que sentia por Plínio; Carlota foi atropelada e Hortência morreu devido a uma hemorragia ocasionada após um aborto espontâneo, o que faz prevalecer a

\footnotetext{
46 FREITAS, 2009, p. 102.
} 
concepção religiosa de que a mulher não virtuosa é punida pelos castigos divinos. Enquanto Plínio, que usufruiu do amor e do prazer vivenciados com cada uma delas, teve um final feliz: casou-se com Adélia, uma prima que era tida como a mulher ideal perante a sociedade e que a ele era prometida há muitos anos, que esperou por Plínio e o aceitou mesmo após ter sido traída/enganada por ele quando se casou e flertou com outras. O que fica subentendido que só é feliz aquela que atende fielmente às normas sociais, morais e religiosas impostas à mulher.

Portanto, pode-se declarar que as personagens de Coisas da Vida, Os Barretos e A besta humana e Mãe dolorosa representam as milhares de mulheres que vêm sofrendo ao longo dos séculos as mais cruéis formas de violências praticadas pelos indivíduos masculinos, simplesmente por não aceitarem a condição de subalterna que a elas foi imposta por eles, frente à sociedade, ou seja, suas vontades.

No que concerne à escrita do autor, pode-se afirmar que ela ratifica o seu caráter conservador no que diz respeito às questões relacionadas às mulheres. Acredita-se que tal posicionamento deve-se ao fato do contexto em que o autor estava inserido na época. Apesar de apresentar múltiplos perfis de comportamento feminino frente à sociedade, o autor permanece resistente às possíveis mudanças das condutas e valores sociais predominantes. As mulheres deveriam assumir os papéis tradicionais de mãe e esposa e aquelas que recusavam o que deveriam compreender como sendo sua "função natural", deveriam ser punidas de alguma maneira, inclusive com a morte.

\section{Referências}

BOURDIEU, Pierre. A dominação masculina. $5^{\mathrm{a}}$ ed. Rio de Janeiro: Bertrand Brasil, 2007.

BOURDIEU, Pierre. O Poder Simbólico. $12^{\mathrm{a}}$ ed. Rio de Janeiro: Bertrand Brasil, 2009. 
CASTELO BRANCO, Pedro Vilarinho. História e Masculinidades: a prática escriturísticas dos literatos e as vivências masculinas no início do século XX. Teresina: EDUFPI, 2008.

COSTA, Mara Lígia Fernandes. A escrita e o desejo: as relações de gênero na produção literária de Clodoaldo Freitas. (Dissertação) Programa de Pósgraduação em História do Brasil, Universidade Federal do Piauí. Teresina, 2010.

DEL PRIORE, Mary; AMARANTINO, Márcia. (Org.). História do corpo no Brasil. São Paulo: UNESP, 2011. p. 477 - 505.

FOUCAULT, Michel. Microfísica do Poder. Rio de Janeiro: Graal, 1979.

FOUCAULT, Michel. Vigiar e punir. Tradução de Raquel Ramalhete. Petrópolis: Vozes, 1987. 288p.

FREITAS, Clodoaldo. Coisas da vida. Imperatriz: Ética, 2009.

FREITAS, Clodoaldo. Um segredo de família e outros contos. Imperatriz: Ética, 2009.

NOVAES, Joana de Vilhena. Beleza e feiura: corpo feminino e regulação social. In:

QUEIROZ, Teresinha. História e Literatura. In:QUEIROZ, Teresinha. Do singular ao plural. Recife: Bagaço, 2006.

PERROT, Michelle. Os excluídos da história: operários, mulheres, prisioneiros. Trad. Denise Bottmann. Rio de Janeiro: Paz e Terra, 1988.

QUEIROZ, Teresinha. Os homens de letras e a política Republicana. In: NASCIMENTO, Alcides; VAINFAS, Ronaldo. História e historiografia. Recife. Edições Bagaço, 2006. p. 466.

QUEIROZ, Teresinha. Os literatos e a República: Clodoaldo Freitas, Higino Cunha e as tiranias do tempo. 2 ed. Teresina: Editora da Universidade Federal do Piauí, 1998. 